First Peoples Child \& Family Review

An Interdisciplinary Journal Honouring the Voices, Perspectives, and Knowledges of First Peoples through Research, Critical Analyses, Stories, Standpoints and Media

Reviews

\title{
Foreword
}

\section{Marlyn Bennett}

Volume 5, Number 1, 2010

URI: https://id.erudit.org/iderudit/1069054ar

DOI: https://doi.org/10.7202/1069054ar

See table of contents

Publisher(s)

First Nations Child and Family Caring Society of Canada

ISSN

1708-489X (print)

2293-6610 (digital)

Explore this journal

Cite this document

Bennett, M. (2010). Foreword. First Peoples Child \& Family Review, 5(1), 4-4.

https://doi.org/10.7202/1069054ar viewed online.

https://apropos.erudit.org/en/users/policy-on-use/ 


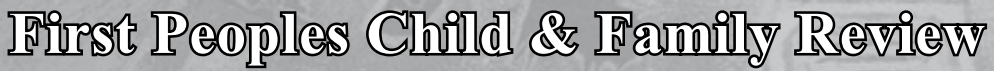

An Interdisciplinary Journal Honoring the Voices, Perspectives and Knowledges of First Peoples through Research, Critical Analyses, Stories, Standpoints and Media Reviews

\section{Volume 5, Number 1, 2010, p. 4}

\section{Foreword:}

\author{
Marlyn Bennett
}

In this issue I have stepped away from my usual role as the coordinating editor of this journal temporarily. I bring words of encouragement, acknowledgement and thanks to our very special guest editor, Jeannine Carriere and the various authors for carrying their knowledge and wisdom forward in this issue. The starting point for this issue was an event called the "Indigenous Gathering and Sharing Wisdom Conference," where the lead organizers were the Indigenous Child Welfare Research Network, partnered with the University of Victoria in delivering evidence-based research at a provincial conference held October 6 and 7, 2009, in Victoria, British Columbia, Canada. The conference sought to highlight and honour research and practices that enrich the lives of Indigenous children and communities. While not all of the articles ( 9 of the 14 in this issue) were presented at the conference, I think you will agree with me that all of the articles in this issue do more than just highlight research being done by, with and for Indigenous populations. The articles honour and enrich not only the lives of Indigenous children, communities, students, Elders and academics, but also those of us who had the privilege of hearing the original conference presentations and those of us who will get to read all or some of the papers that have resulted in this issue.
This issue also highlights an unusual practice in that it is dedicated to a young conference presenter who lost her life un-expectantly a short time after the conclusion of the Indigenous Gathering and Sharing Wisdom Conference. It was important to the conference organizations that we acknowledge Roxanne Charlie and her dedication to better the world for herself, her family and her community. We know that her star shines brightly across the paths of her family, friends and communities today.

I want to close by saying Miigwetch (thank you) for the opportunity to partner in bringing forth the sharing and knowledge that was imparted during this important conference and to acknowledge the important contributions of all the authors to this issue of the First Peoples Child and Family Review journal. Enjoy the read!

Marlyn Bennett, Director of Research and Coordinating Editor of the First Peoples Child \& Family Review Journal, First Nations Child \& Family Caring Society of Canada 